\title{
The Cytotoxic Effects of Eggplant Peel Extract on Human Gastric Adenocarcinoma Cells and Normal Cells
}

\author{
Fatemeh Afshari ${ }^{1}$, Hoda Seraj ${ }^{1}$, Zahra Sadat Hashemi ${ }^{1}$, Marziyeh Timajchi ${ }^{2}$, Ensiyeh \\ Olamafar ${ }^{1}$, Ladan Ghotbi ${ }^{1}$, Masoomeh Asadi ${ }^{2}$, Zahra Elyasi ${ }^{2}$; Meysam Ganjibakhsh ${ }^{2 *}$
}

1. Rah-e Shayestegan Co, Tehran, Iran

2. Jahad-e Daneshgahi, National center for genetic and biological resources of Iran, bank of human and animal cells, Tehran, Iran

\section{KEYWORDS}

\begin{tabular}{c}
\hline \\
Eggplant \\
Antioxidant \\
Cancer \\
MTT test \\
\hline Article Info \\
\hline
\end{tabular}

Received 2018/06/02;

Accepted 2018/07/20;

Published Online 2018

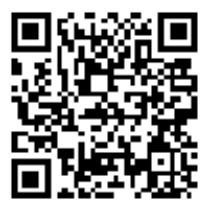

\section{ABSTRACT}

Background and Objectives: Gastric cancer is the fourth common and the second deadliest cancer worldwide. Its major causes of outbreak are genetic factors and the life style, like eating fast foods, physical inactivity, environmental pollution, and other natural factors.

Methods: The article, which is conducted in human and animal cell bank of Iranian genetic and biological resource center evaluated the cytotoxic effects of the eggplant peel extract on human gastric cancer cells and normal cells. During this experiment, all quality control stages performed on cell lines, including bacteria, fungi, yeast, mold, mycoplasma, as well as HIV-I, HVB, HCV, EBV viruses, and the results of negative tests were reported. The MTT test was used to establish the cytotoxicity of the material and to define the amount of $\mathrm{IC}_{50}$.

Results: The obtained results indicated that the toxic impact of active eggplant extract ingredient on the cancer cells is more than the normal cells and it is noteworthy that, compared to the normal cells the mortality rate of the cancer cells in three concentrations shows a significant difference.

Conclusion: It is highly recommended that the eggplant extract, as an anticancer food, be evaluated more in future research studies.

Corresponding Information: Dr. Meysam Ganjibakhsh, Human and Animal Cell Bank, Iranian Genetic and Biological Resource Center, Tehran, Iran. Email:meysam_ganjy@yahoo.com. Tel: +98-21-88525389

Copyright $(\odot$ 2018. This is an open-access article distributed under the terms of the Creative Commons Attribution-noncommercial 4.0 International License which permits copy and redistribute the material just in noncommercial usages, provided the original work is properly cited.

\section{Introduction}

Gastric cancer is the fourth common and the second deadliest cancer worldwide (1). Its major causes of outbreak are genetic factors and the lifestyle, like eating fast foods, physical inactivity, environmental pollution, and other natural factors (2). Cell mutation brings about their resistance to the apoptosis process and could cause the cells to consume all their energy for proliferation and survival. One way to cure the cancer is to use deathinducing chemical compounds and herbal extracts in cancerous cells. Scholars declared that the use of plant-based diets could mitigate the risk of cancer. The potential use of plants, however, as a novel medicinal resource, has not been studied sufficiently. Among 500 thousands existing plant species in the world only a short percentage of them have been investigated in terms of their medicinal effect (3).

Plant nutrients, like carotenoids, tocopherols, ascorbic acid derivatives, and non-nutrient compounds, which are called phytochemicals, decrease the outbreak of different cancers in human. Eggplant is one of the plants with medicinal use. Hence, as it is shown in the present article the plant has potential anticancer and antioxidant effect. The existing active ingredient of the eggplant, which might have antioxidant properties, is called delphinidin 3-5- galactoside. The substance has protective activity against lipid peroxide (4). Moreover, chlorogenic acid is the most abundant 
phenolic acid, which account for $75 \%$ of the eggplant (5). Although some vegetables, like eggplant, have high antioxidant activities able to prevent the diseases, further research studies are needed to substantiate the claim (6).

The present article, which is conducted in the bank of human and animal cells of Iranian genetic and biology resource center evaluated the cytotoxic effects of the eggplant peel extract on human gastric cancer cells and normal cells for its antioxidant properties using the MTT test. During the test, all quality control stages were performed on cell lines, like microbial quality control including bacteria, fungi, yeast, molds, mycoplasma, as well as virus quality control, like HIV- I, HBV, HCV, EBV. The aim of the study was to evaluate the antioxidant effect and the potential anticancer capacity of the eggplant peel extract on human gastric adenocarcinoma cell line and the normal cell line.

\section{Materials and methods \\ Preparing alcoholic extract of the eggplant peel}

In order to prepare the alcoholic extract, $100 \mathrm{gr}$. of eggplant peel was mixed with the absolute ethanol. After grinding the eggplant peel through a mixer machine, the mixture stored at $-40^{\circ} \mathrm{C}$ for 48 hours in a bain-marie, then passed through a paper filter to separate the insoluble and coarse particles. Next, the residual extract alcohol removed by the evaporation method. In the end, the obtained dried materials weighted by a digital scale and using the DMEM medium, 10, 5, 2.5, 1.25, 0.6, 0.3, 0.15, $0.06,0.03,0.01$ concentrations were provided and passed through a 0.22 micrometer syringe filter to sterilize the provided extract.

\section{Preparing cell lines}

In this paper, human gastric adenocarcinoma cell line (IBRC C10018) and human normal cell line (IBRCC10309) were cultured in accordance with their ID number in DNEM complete medium containing $10 \%$ FBS.

\section{Quality control of cell lines}

Prior to any test performance, we must be ensured that the cells are not contaminated with the microorganisms. Mycoplasma contamination, for example, is one of the major issues of the researchers working in the cell culture, in that a contaminated cell could cause a decline in cell amplification, disorder in the test procedure, and defect in proper data. Moreover, bacteria, fungi, molds, and viruses count as other sources of hazardous contamination in cell culture. In order to diagnose the mycoplasma contamination, three DNA painting methods, namely Hoechst method, molecular detection by polymerase chain reaction (PCR), and specific mycoplasma direct culture were employed. Within these tests, intraspecific (STR) and interspecific (test of specie differentiation) tests were used to determine the identity of cell lines. Furthermore, all viral and microbial quality control procedures, including bacteria, fungi, molds, as well as viruses, like HIV-I, HBV, HCV, and EBV were performed, as well.

The multiplex PCR technique employed to conduct the mycoplasma quality control test using the PCR method. The technique comprises seven pairs of forward primer and three pairs of reverse primes. Another microbial tests using specific bacterial and fungal mediums carried out under the name, PPLO Broth and PpLo Agar. In the case of viral HIV-I, HBV, and HCB tests, STRP-HIVDetection Kit (Sinaclon), Hepatit B Detection Kit (Sinaclon), and STRP-HCV-Detection Kit (Sinaclon) were used, respectively. The EBV viral test was performed according to a regulated PCR program in the laboratory with the specific primers.

\section{MTT test}

First, $100 \mu \mathrm{l}$ of cellular suspension containing 5 thousand cells were added to each well of a 96well container and cells were incubated for 16 hours in $5 \% \mathrm{CO}_{2}$ and $100 \%$ humidity condition, at $37^{\circ} \mathrm{C}$. After incubation, different concentrations of the eggplant peel extract were added to the cancerous and normal cells and cells were stored in the same condition for another 48 hours. Then, $10 \mu \mathrm{l}$ of MTT color was added to each well of a 96-well container with the final concentration of $5 \mathrm{mg} / \mathrm{ml}$. Three wells containing $100 \mu \mathrm{l}$ of the medium and $10 \mu \mathrm{l}$ of MTT color, were set for the negative control and another three wells containing total medium and $5 \%$ of DMSO substance, were set as the positive control of the test. 
The desired container wrapped for three hours in an aluminum foil and incubated in $5 \% \mathrm{CO}_{2}$ and $100 \%$ humidity condition at $37{ }^{\circ} \mathrm{C}$. Then, wells' medium was evacuated and $100 \mu \mathrm{l}$ of the DMSO solution added to each well and the container was put in a dark place for one more hour. Next, wells' absorption, including samples, negative control, and positive control was read by a Spectrophotometer at the wavelength of 570 nanometers and the amount of specific absorption for the desired sample calculated according to the following formula.

Sample absorption at $660 \mathrm{~nm}$ - blank absorption at $570 \mathrm{~nm}$ - sample absorption at $570 \mathrm{~nm}=$ the amount of specific absorption

It is worth mentioning that each MTT test performed triplicated to minimize errors during the test.

\section{Evaluating the morphological changes of cells}

Before adding the eggplant peel extract, cells were evaluated in terms of morphological and qualitative indices of cell health, like the presence of granules around the core and vacuoles in the cytoplasm of the cell, and any alteration in the general cell features (cell adhesion and suspension). After cell treatment with different eggplant peel extract concentrations, cells were assessed once more through a microscope.

\section{Statistical analysis}

All data were reported on average, results were analyzed using the SPSS software version 17, and One Way ANOVA and Student's t-test methods were employed.

\section{Results \\ Quality control of cell lines}

Comprehensive evaluation, including intraspecific (STR), interspecific (test of specie differentiation) tests, and all quality control procedures, containing bacteria, mycoplasma, fungi, molds, as well as viruses, like HIV-I, BV, $\mathrm{HCB}$, and EBV were carried out in the human and animal cell bank of Iranian genetic and biological resource center (figure 1 and 2).

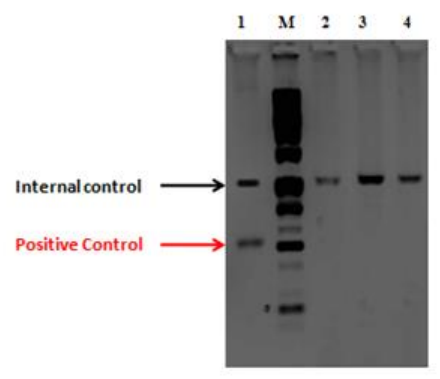

Lane 1: Positive Control Lane 2: Sample (AGS cell line) Lane 3: Sample (Hu-02 cell line) Lane 4: Negative Control

Figure 1. mycoplasma quality control test using the PCR method

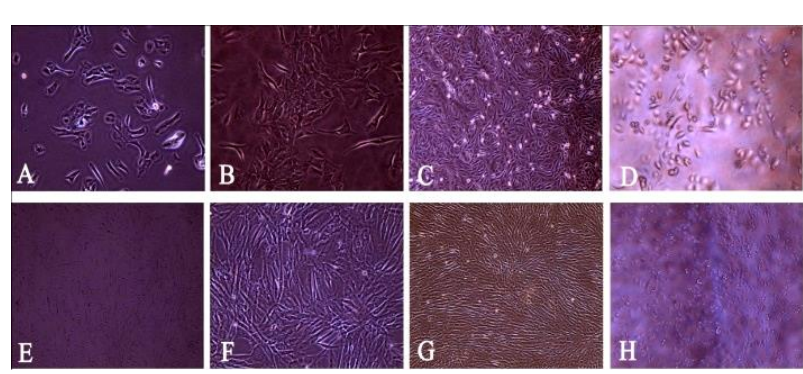

Figure 2. evaluating mycoplasmatic infection in cell lines using DNA painting (Hoechst method)

\section{Evaluating the morphological changes of cells}

Before adding the eggplant peel extract, cells were evaluated in terms of morphological and qualitative indices of cell health and as it is shown in figure 3, before treatment, cells have no granules around the core and no alteration in their general features (cell adhesion and suspension). After cell treatment with different concentrations of the eggplant peel extract, they were assessed once more through a microscope. There have seen some granules around the core in the toxic concentrations, some expanded cell sizes, and some cells with lost adhesion and suspended condition. These symbols indicate that at the presence of this extract cells viability goes down and the amount of apoptosis in treated cells have raised. 


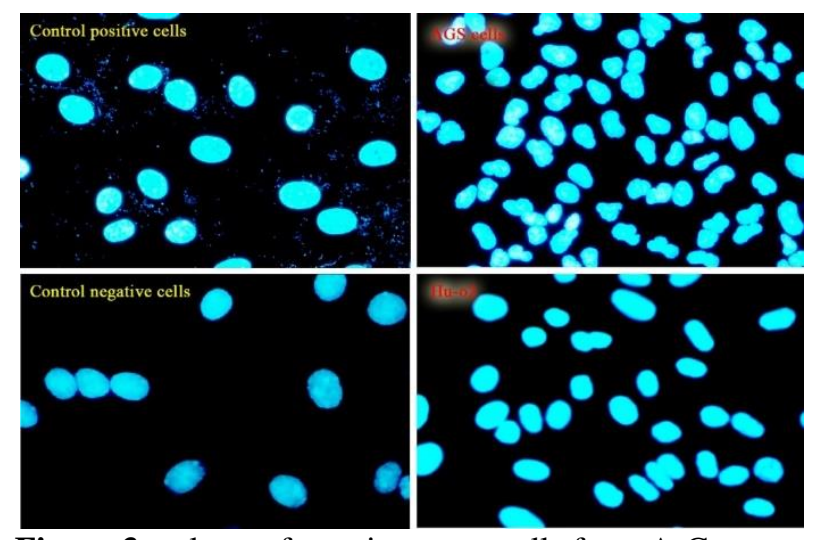

Figure 3. culture of gastric cancer cells from A-C pictures without the addition of the extract, figure $\mathrm{D}$ the effect of the extract on the cancerous cells, which is indicative of the cell death. Proliferation procedure of normal cells from E-G without addition of the extract, figure $\mathrm{H}$ the toxic effect of extract on the normal cells. Cells magnification: $10 \mathrm{X}$

\section{MTT test}

The MTT test was carried out using cell treatments in $10,5,2.5,1.25,0.6,0.3,0.15,0.06$, $0.03,0.01 \mathrm{mg} / \mathrm{ml}$ concentrations during 48 hours. The amount of IC50 (IC50 is equal to a concentration of the extract, in which $50 \%$ of cells are rescued) for the cancerous and normal cells is 1.87 and $5.2 \mathrm{mg} / \mathrm{ml}$, respectively. As it is shown in diagram 1, the viability of cancer cells in values of $0.6,1.2$, and $2.5 \mathrm{mg} / \mathrm{ml}$ of the extract is less than the normal cells. It is clearly evident that concerning the obtained results from MTT test and the amount of IC50 in normal and cancerous cells, the toxic effect of the active ingredient of the eggplant peel extract on cancerous cells is more than the normal cells and it is noteworthy that the mortality rate of the cancer cells in three concentrations of $2.5,1.25$, and 0.75 has a significant difference from the normal cells (Figure 4).

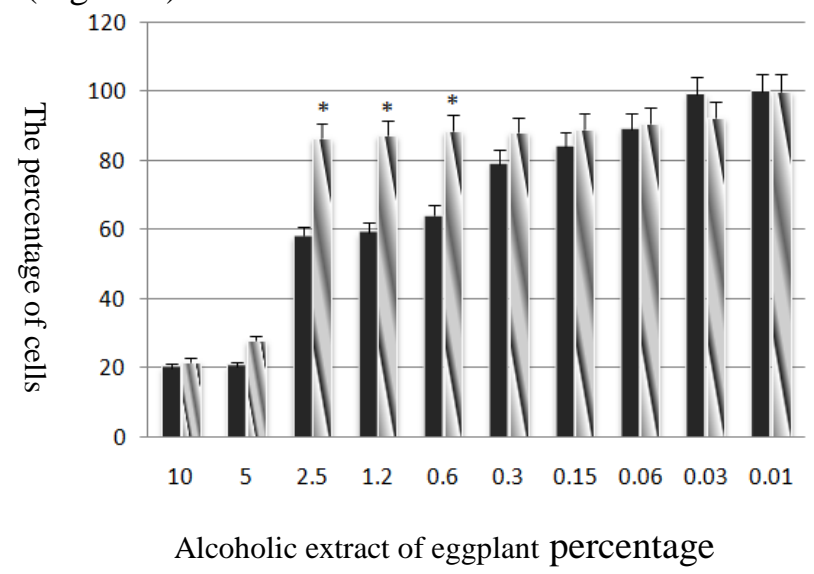

Figure 4. the cytotoxic effect of alcoholic extract of eggplant peel on gastric cancer cells and normal cells

\section{: gastric cancer cells $\mid$ : Norma Cells}

\section{Discussion}

Baracci et al. (2003) conducted a study on the effect of medicinal properties of plants on the public health and suggested that every person should consume $500 \mathrm{gr}$. fruits and vegetables per day since this class of foods have high nutritional value and are good sources of vitamins, minerals, and fibers (7). In addition, American Heart Association prohibited the use of supplements such as antioxidant vitamins, but put a great emphasis on consumption of food containing high levels of vitamins. For example, studies indicated that since the green tea is a source of catechin compounds it prevents the outbreak of blood and liver cancer, effectively (8). Some other reports were also published of unique phytochemical ingredients and compounds substantiating the anticancer properties of plants. It is almost 40 years that intensive research studies have carried out on the relationship between foods and chronic diseases (9). During this period, spectacular advances were made in the relationship between food and cancer (10). It is also proved that the available eggplant anthocyanin is mainly contained of delphinidin 3-rutinoside compound (11), called tulipalin, which is a glycoside anthocyanin and its high antioxidant property is verified. Eggplant can grow in moderate subtropical regions and bears high temperature for a long period of time. To consume the eggplant with its maximum quality, it should be picked before it has large seeds $(12,13)$.

In this test, potential antitumor properties of the eggplant were evaluated in human gastric cancer (ASG) and normal fibroblast cells using the MTT technique (based on cytotoxicity test). Under laboratory conditions, decline in the number of cells, using an active ingredient, explained by cell death or their growth prevention. The effective dose of the desired substance, in which half of the cells will be killed was considered as toxicity criteria (14). Results have shown that the eggplant, by having rich phenolic components and high antioxidant activity could be a defensive barrier 
against the free radicals. Therefore, eggplant could be consumed as a preventive food against the outbreak of cancer, in that it is believed that the antioxidant activity hinders the outbreak of cancer (15). In the present article, there is an appropriate relationship between the cytotoxic effects of eggplant extract and antioxidant activity. On the other hand, chemotherapy is one of the methods of cancer treatment, but often lack of selective cytotoxicity could cause unbearable complications. Currently, use of medicinal plants in cancer treatment due to their fewer complications is fairly significant. With regard to the results of this project, we could claim that use of eggplant peel extract in producing gastric anticancer drugs could have a principal role. Moreover, cancer is the third mortality factor in Iran and gastric cancer is one of the deadliest. The prevalence of this disease is two times more common among men than women and is the fourth most common cancer worldwide $(5,10$, 16). After the lung cancer in men and the breast cancer in women, gastric cancer is the most prevalent cancer. In addition, it is recognized that the gastric cancer is more widespread in lower social-economic class. Those immigrant, who moved from more common to less common areas preserved their previous tendency, but the risk of infection in their children adapted to the current place of living. This finding indicates there should be an environmental factor affecting the host in his/her early ages and causing the gastric cancer. Consequently, cancerous factors are more important than other issues in the daily diet $(17,18)$. Eggplant peel is rich in antioxidant compounds, which cause the resistance of human cells against premature aging. The existing phenoline in the eggplant mitigates the amount of blood cholesterol, and at the same time prevents the abnormalities in the genetic material and hinders the formation of cancerous tissues. However, is it highly recommended not to indulge in eating eggplant, because it contains oxalate, which brings about the formation of kidney stones $(19,20)$. Moreover, the existing phytochemical in the eggplant could treat a type of skin cancer with a tremendous power. In traditional medicine of Australia, farmers treat the eye cancer, which is common among the animals of the region and one of its major factors is sunray and lack of ozone in air, by the eggplant (21). The phenolic compounds of the eggplant have the antioxidant effect and protect the body against a variety of bacterial and viral infections. On the other hand, there is an antioxidant in its peel, called anthocyanin, protecting the outbreak of heart diseases. Hence, we recommend eating eggplant boiled with its peel (22-24).

In the end, we could say that regarding the potential properties of this plant, further research studies are needed on available bioactive compounds of the extract of this plant and its probable mechanisms to recognize its unique properties more immensely.

\section{Acknowledgement}

Thanks to Bahar Tashkhis Teb Inc. for free translation and scientific editing services.

\section{Conflict of interest}

The authors declare that there is no conflict of interests

\section{References}

1. Zhao Y, Feng F, Zhou YN. Stem cells in gastric cancer. World journal of gastroenterology. 2015;21(1):112-23.

2. Hurt RT, Kulisek C, Buchanan LA, McClave SA. The obesity epidemic: challenges, health initiatives, and implications for gastroenterologists. Gastroenterology \& hepatology. 2010;6(12):780-92.

3. Rates SM. Plants as source of drugs. Toxicon : official journal of the International Society on Toxinology. 2001;39(5):603-13.

4. Noda Y, Kneyuki T, Igarashi K, Mori A, Packer L. Antioxidant activity of nasunin, an anthocyanin in eggplant peels. Toxicology. 2000;148(2-3):119-23.

5. Luthria DL, Mukhopadhyay S. Influence of sample preparation on assay of phenolic acids from eggplant. Journal of agricultural and food chemistry. 2006;54(1):41-7. 
6. Salerno L, Modica MN, Pittala V, Romeo G, Siracusa MA, Di Giacomo C, et al. Antioxidant activity and phenolic content of microwave-assisted Solanum melongena extracts. ScientificWorldJournal. 2014;2014:719486.

7. Bayan L, Koulivand PH, Gorji A. Garlic: a review of potential therapeutic effects. Avicenna journal of phytomedicine. 2014;4(1):1-14.

8. Dufresne CJ, Farnworth ER. A review of latest research findings on the health promotion properties of tea. The Journal of nutritional biochemistry. 2001;12(7):404-21.

9. Vujicic M, Nikolic I, Kontogianni VG, Saksida T, Charisiadis P, OrescaninDusic Z, et al. Methanolic extract of Origanum vulgare ameliorates type 1 diabetes through antioxidant, antiinflammatory and anti-apoptotic activity. Br J Nutr. 2015;113(5):770-82.

10. Weisburger JH, Chung FL. Mechanisms of chronic disease causation by nutritional factors and tobacco products and their prevention by tea polyphenols. Food and chemical toxicology : an international journal published for the British Industrial Biological Research Association. 2002;40(8):1145-54.

11.Zou T, Wang D, Guo H, Zhu Y, Luo $X$, Liu F, et al. Optimization of microwave-assisted extraction of anthocyanins from mulberry and identification of anthocyanins in extract using HPLC-ESI-MS. J Food Sci. 2012;77(1):C46-50.

12. Solis PN, Wright CW, Anderson MM, Gupta MP, Phillipson JD. A microwell cytotoxicity assay using Artemia salina (brine shrimp). Planta medica. 1993;59(3):250-2.

13. Azuma K, Ohyama A, Ippoushi K, Ichiyanagi T, Takeuchi A, Saito T, et al. Structures and antioxidant activity of anthocyanins in many accessions of eggplant and its related species. Journal of agricultural and food chemistry. 2008;56(21):10154-9.

14. Smit HF, Woerdenbag HJ, Singh RH, Meulenbeld GJ, Labadie RP, Zwaving JH. Ayurvedic herbal drugs with possible cytostatic activity. Journal of ethnopharmacology. 1995;47(2):75-84.

15. Ames BN. Dietary carcinogens and anticarcinogens. Oxygen radicals and degenerative diseases. Science. 1983;221(4617):1256-64.

16. Suresh R, Ali S, Ahmad A, Philip PA, Sarkar FH. The Role of Cancer Stem Cells in Recurrent and Drug-Resistant Lung Cancer. Advances in experimental medicine and biology. 2016;890:57-74.

17. Balunas MJ, Kinghorn AD. Drug discovery from medicinal plants. Life sciences. 2005;78(5):431-41.

18. Wiseman M. The second World Cancer Research Fund/American Institute for Cancer Research expert report. Food, nutrition, physical activity, and the prevention of cancer: a global perspective. The Proceedings of the Nutrition Society. 2008;67(3):253-6.

19. Prasain JK, Barnes S. Metabolism and bioavailability of flavonoids in chemoprevention: current analytical strategies and future prospectus. Molecular pharmaceutics. 2007;4(6):846-64.

20. Vance TM, Su J, Fontham ET, Koo SI, Chun OK. Dietary antioxidants and prostate cancer: a review. Nutrition and cancer. 2013;65(6):793-801.

21. Kocic B, Kitic D, Brankovic S. Dietary flavonoid intake and colorectal cancer risk: evidence from human population studies. Journal of BUON : official journal of the Balkan Union of Oncology. 2013;18(1):34-43.

22. Neuhouser ML. Dietary flavonoids and cancer risk: evidence from human population studies. Nutrition and cancer. 2004;50(1):1-7.

23. Middleton E, Jr., Kandaswami C, Theoharides TC. The effects of plant flavonoids on mammalian cells: 
implications for inflammation, heart disease, and cancer. Pharmacological reviews. 2000;52(4):673-751.

24. Borek C. Dietary antioxidants and human cancer. Integrative cancer therapies. 2004;3(4):333-41.

\section{How to cite this article}

Afshari F, Seraj H, Sadat Hashemi Z, Timajchi M, Ensiyeh O, Ladan G, et al . The Cytotoxic Effects of Eggplant Peel Extract on Human Gastric Adenocarcinoma Cells and Normal Cells. Mod Med Lab J. $2018 ; 1$ (2) :77-83 